\title{
The Politics of Pulpit Religiosity in the Era of Covid-19 in Kenya
}

\section{Susan M. Kilonzo* and Bryson O. Omwalo \\ School of Arts and Social Sciences, Maseno University, Kisumu, Kenya}

This essay centres on the role of religion in the era of Covid-19. We juxtapose social media and religious practices in a way that challenges the conventional religion of the pulpit to deconstruct the myths and misconceptions around spirituality in the era of Covid-19. We show the transformation of worship from physical worship places, particularly churches, to virtual engagements through social media. Through observation, close relations' accounts, personal experiences and media perspectives, we analyze the politics that surrounded religious observances in the first 7 months of Covid-19 pandemic in Kenya. We make a case that, discoveries made in these seven and other months to come, will most likely influenced the myths and misconceptions about religion and religious practices in the Country. From these accounts, we project a future that is likely to reap from the benefits of technology, and especially social media, which has revolutionized exchange of ideas, sermons, prayers and music. We challenge the very notion of pulpit religiosity, and the myths and misconceptions that religion cannot be without physical fellowships.

Keywords: politics, pulpit religiosity, CovID-19, Kenya, social media

\section{INTRODUCTION}

Covid-19 took the world by a storm. It paralyzed the global systems and disoriented the norm in almost all parts of the world. It has had far reaching effects on the globe, with economies. The global effects as Ozili and Arun (2020) show, led to shutdown of financial markets, corporate offices, businesses and events. Only a number of these could manage to fully shift their offices online. The spread of the virus also brought uncertainty, and as people grappled in the dark without knowledge of how the spread would unfold, and when it will be curtailed, Ozili and Arun (2020) make a mention that, there was an observed flight to safety in consumption and investment among consumers, investors and international trade partners, further affecting the economies. Among other serious ramifications of the virus, besides stretched health care systems and massive deaths, it was clear that the world had been caught on the wrong foot by a disease whose main threat lie on its mode of spread than on the fatality rate, especially for the African countries. The first case in the continent was confirmed in Egypt in early February 2020. On March 5, 2020, South Africa recorded its first case. Kenya recorded her first on March 12, 2020. Comparatively, however, Africa has had low fatality rate compared to the West. And Several theories and pseudo-myths emerged to explain this disparity. One of those was that, biologically, Africans have stronger genes and therefore more resistant to such viral infections. Another myth propagated was, African temperatures are not conducive for the survival and replication of the virus. Others were that African population has affinity to natural foods, which are immune boosters. They are said to use plants such as lemon, ginger and other natural plants/ herbs, that are believed to help the body fight diseases. A trajectory of these myths was flung by the President of a country in the Eastern African region who confirmed that his own child who 
contracted the virus recovered after using steam therapy and taking a lot of garlic and lemon. Indeed, Madagascar, more assertively, grabbed international limelight when their President announced that they had a remedy to the pandemic. In April 2020, the Madagascar Institute of Applied Research (IMRA), which describes itself as "dedicated to biodiversity conservation and the discovery of drugs from natural products" announced the development of Covid Organics (CVO) from the artemisa plant and which the country promoted as a remedy for covid-19. The country was willing to export their newfound wonder drug to other countries. On June 8, 2020, a President of an Eastern African nation declared his State corona-free and attributed this to the prayers offered by the citizens (https://www.bbc. com/news/world-africa-52966016, Accessed July 12, 2020). The President constantly invoked the name of God in his campaign against the coronavirus pandemic. In Mombasa, Kenya, a baby is reported to have been born proclaiming that black tea was the cure for coronavirus. Many of these myths were propagated as people desperately grappled in the dark for a cure to this virus that was perceived to be worse than anything humanity have ever experienced. The myths served to give hope and faith that, cure was around the corner.

These and other accounts raise a number of questions about the myths and misconceptions on what religion can or cannot do in the era of pandemics. It further raises concerns about the misleading information that is likely to escalate effects of serious pandemics in the continent. These misconceptions seem to have held in some contexts albeit the widely spread health messages on social distancing, use of Masks, washing of hands, and, in the latter days, vaccinations and avoiding work places in favour of working at home, where possible. These messages were widely by Ministries of Health in various countries, World Health Organization, and varied bodies locally and internationally. The messages cascaded to institutional and individual responsibility; including religious bodies and leadership. The essay therefore centres on the role of religion in the era of pandemics. We examine the options that faithfuls have when the norm is disrupted. These are the alternative means of worship and fellowship, inter-personal relations, relevance of the clergy, and the central role of social media in a growing turbulence and moments of uncertainty. We explore the myths and misconceptions around pulpit religiosity by showing that, for over 7 months in Kenya, and other African countries, outward forms of religiosity were not a necessary condition for people's spiritual lives to continue. We focus on Christianity, to show that the notion of physical meetings and pulpit sermons was challenged during the pandemic. As the essay shows, the ban of congregations amplified virtual, personal and family religiosity. Faithfuls kept the hope through available mainstream and social media platforms. Even when the government provided a leeway for 100 members of each church, mosque or temple to attend one-hour physical worship, the masses were reluctant for a number of reasons. Mega Churches with megastructures and a capacity to contain over 100 people comfortably, felt that the rules were arbitrary and had no scientific basis. For instance, mega Seventh Day Adventist Church in Kisumu, with a capacity for 1500 people expressed challenges of maintaining the number at 100 arguing that for they needed to conduct 15 services every Saturday to serve their faithful.

\section{CONCEPTUALIZING RELIGION AND TECHNOLOGY IN AFRICA}

Technological advancement has meant a revolution in virtually all the fields of human life. Before this revolution, in religious circles, "God," would be accessed in standard, routinized, predictable and more conventional ways (Nyamjoh, 2015). In the African context specifically, transmission of the gospel was face-to-face, in churches, and communities of worship. This still persists in some of the mainstream missionary churches in Africa, where Amanze and Wogu (2015) observe an unharnessed potential of the Internet for soul-winning. Nevertheless, there exists vast literature on the use of media by churches for evangelism and other activities. Studies show that churches have in the past used mainstream media to spread gospel faster and wider (Asamoah-Gyandu, 2005; Togarasei, 2012). Although most of the literature published before the new millennium centers on mainstream media, including television, radio, internet and print media (Cox 1995; Coleman 1998; Hackett 1998 and Gyandu), recent studies pay attention to other forms of media including social media (Togarasei, 2012; Togarasei, 2015). Of attention from these scholarly works has been the use of technology in Pentecostalism, a Christian movement that has swept the continent with might in the last three or so decades. This is because as Togarasei (2012) indicates, Pentecostalism may be more liberal in adoption of new waves of development as opposed to African independent Churches that may view such processes as trivializing Christianity. In Pentecostal/Charismatic Churches and especially as mediated by the Gospel of prosperity (Meyer, 2003; Ukah, 2006), use of print, mainstream and social media is vibrant. Asamoah-Gyadu (2015), in an article on "We are on the Internet" explains what the technological revolution has meant on human relationships in Pentecostal Christianity. In another piece, "Anointing through the screen," he shows how televangelism has transformed how people access the word of God (Asamoah-Gyadu, 2005). Although most of this literature focus on the use of mainstream media especially in the Pentecostal churches, the use of social media in evangelism and other church activities has been happening along the traditional face to face Church services even in the developed world.

In Kenya, Internet and mobile technology has quite advanced. This is against the backdrop of increasing ownership of smartphones, tablets and increased Internet connection. There were 22.86 million Internet users in Kenya in January 2020, which was a $16 \%$ increase between 2019 and 2020 , and a penetration of $43 \%$. There were 8.80 social media users in January 2020, with an increase of $13 \%$ between April 2019 and January 2020. Around the same time, there were 52.06 million mobile connections in January 2020. This is an indication of multiple phone ownership given the 
total population in the country of 50 million, including children. The number of mobile connections increased by 4.3 million in 1 year, between January 2019 and January 2020 (https://datareportal.com/reports/digital-2020-kenya, accessed October 9, 2020). A study done by Delloitte (2019) in Kenya shows that WhatsApp, Facebook, Instagram and These statistics are an indication of exponential growth in Kenya's technology, which has implications in human relationships and interactions in all domains.

Mobile money transfer services including MPESA, Airtel Money, M-Shwari, MCHANGA, FULIZA, among many, have meant that the access to both the Gospel and servicing the Church with tithes and offerings is not dictated by physical proximity. In fact, churches have encouraged the use of these services to tithe and make other contributions to churches' development project. The churches have Till and PayBill numbers. This corresponds research done by Delloitte (2019) in Kenya which showed that "the rise of mobile payments in Kenya has been facilitated mostly through network operators and the multiple banking apps that allow people to purchase, transfer money and pay for the various services in their day to day lives. Businesses in Kenya have invested in options for customers to pay through their phones through mobile payment options such as till numbers and network operator services," p.13. With societies becoming more and more cashless, the Church has to adapt too. However, regardless of the milestones that churches had made through the use of technology, face-to-face fellowships, dubbed in this paper, pulpit religiosity, continue. As we shall soon see, there is a reason why the church leaders need physical interaction with their followers.

Further, churches have also explored the use of technologies in praise and worship. The music, as produced with the advanced technology, has moved beyond the drum, shakers and tambourines used in traditional mainstream churches. It now borders any other secular music that uses all the possible beats. Carl (2015) explored the intersection of the sacred and the secular in the ways people understand and negotiate religious practice and style in Charismatic Churches in Ghana. He shows how dancing styles and song circulate in the mediascape. They then seep into the church services through WhatsApp, Facebook, Youtube and further to the public for comments and debates. These and other related trends seem to be explored more within the vibrancy of technological advancement and Pentecostalism as well as charismatic domains. It is not clear from literature whether this is the same trend among the AICs, as Togarasei (2012) notes that these have been slow in adopting technologies. In the wave of technological advancement, there should somehow be a change in the ways in which the worshippers in these African tradition-oriented Churches virtually share, relate and access gospel. There is a likelihood that their histories, geographical spaces and traditions have been permeated to a great extent by the Internet, WhatApp, Youtube, Mobile Telephony, Mobile Money Transfers, and the like to transform the ways in which they access the gospel and interrelate. Though these churches seem to be absent on television networks and radios, this does not imply they are totally absent in social media for instance, which is almost free as compared the mainstream technology platforms like radio and television.
Hardly have studies in the past paid attention to role of social media on religion in an era of pandemic. This paper argues that the notion of the dichotomy of African culture and the use of technology may have been broken by the Covid-19 wave even for the mainstream churches that consider themselves "traditional." The discourse of pandemics in this era of social media seem to have unleashed potential of technology regardless of the inhibitors. Further, the perception of geographical spaces and a kind of religiosity that can only be appropriated through face-to-face pulpit sermons seem to have been redefined. Social media became the medium of human relationships and religiosity.

\section{RELIGION AND COVID-19 IN KENYA}

At the onset of the pandemic in Kenya on March 12, 2020, when the first case was announced, Kenyans knew it was just a matter of time given the central role of Jomo Kenyatta International Airport (JKIA) in the region. Within 3 days, the government gave ultimatums for schools to close within a week and provided other containment measures in a bid to curb exponential spread of the virus. Amongst these containment measures, and of significance to this essay was the ban on all kinds of gatherings, which included religious gatherings. Houses of worship such as Churches, Mosques, and Temples were all closed for worship services indefinitely. Further, restaurants and pubs; schools; funerals; markets and any other social places were understood to be epicenters of spread of Covid-19. Closure for churches was necessitated by the fear that in normal circumstances, it would not be easy to maintain social distance, a critical precautionary condition in the fight against Covid-19, during worship services. Health officials were quick to draw analogies between the deaths that had occurred in Italy and the possible outcomes in Kenya if such gatherings as church services were allowed. In a Press conference, the Cabinet Secretary in charge of health was quoted as saying "Let us not forget that Italy began its unfortunate experience through the decision of some people to continue attending gatherings, including religious ones..." (Sunday March 22, 2020). His fears seemed to have been corroborated when it was reported, in the same month of March, a Catholic Priest returning home from Rome tested positive for the Virus after he already had interacted with community members and officiated a mass in the village. After the Priest was released from the hospital, he was charged with evading tests at the JKIA and not self-quarantining for 14 days on arrival in the country. He was later released. In another instance, a prominent Bishop of a Pentecostal Church in Nairobi tested positive and was hospitalized. Such instances were used to amplify the great risks gatherings in places of worship held, and strengthening the resolve to maintain a total ban on the same.

Churches reacted in varying ways to the ban on Church services. First there was a reluctance to accept this ban. One of the Archbishops of the Catholic Diocese in response to this ban argued that it was unfair to label the Church as a possible contributor to the crisis arguing that the Catholic Church, for 
instance, has always played a critical role in providing healthcare to Kenyans. Of course, this was out of ignorance on the part of the leader since the disease had just made its way into the country and there was no sufficient information on modes of transmission and ways to curb the spread. A more defiant reaction was witnessed on March 22, 2020, when Police stormed a Pentecostal Church in Mombasa where a service was in progress and made arrests of the congregants. The congregants here argued that the God they had come to worship was greater than Covid-19 and science. They were quick to remind people that it is in the Church that the solution to the pandemic could be found. Another misconception. On march 29, 2020, another defiant act by a Pastor of a Pentecostal Church in Kitale in Western Kenya was arrested alongside 20 worshipers for carrying out their normal Sunday services, the government directive notwithstanding. On April 5, 2020, more than 20 worshippers of one of the African Independent Churches were arrested in Usenge in Western Kenya, for conducting a Church service. Many more arrests were made for the open defiance of this particular Government directive. Churches that never came out openly to defy this order were characterized by mute acquiescence and resignation to the directive, advising their members to obey the government directives by not coming for services, but to remain prayerful and ever vigilant as these were apocalyptically interpreted as the signs of the end times.

The actions of defiance had a basis in the spiritual interpretation by a number of Churches and religious leaders that banning church services on the basis that these are bases for the spread of the disease was an outright challenge to a very critical role and existence of the Church. To them, faith healing and the Church as the ultimate place of refuge from a restless sick world, is a major plank upon which the Church is established. The ban was therefore interpreted to be a total subversion of the place of the church in the contemporary world. In a few places the ban and the ensuing global condition occasioned by the pandemic was seen as the onset of the apocalypse forewarned in the book of Revelation that would be preceded by the mark of the beast. Corona was, in this perspective, the forerunner of the mark of the beast. Others instigated the Church to take on the government on its directives by indicating that, the bible prohibits Christians from conforming to the world but instead should transform the world. For this lot, adhering to the protocols established to govern the manner in which the church must operate is abdicating the Christian responsibility and is tantamount to conforming to the world. Such misconceptions found no hearing from the side of the government stood its ground. There was simply not going to be public worship for as long as the spread of the virus continued. Church doors were to remain.

Following these developments, religious sector is one of those that were hit hard by the pandemic and compelled to take a new look at its modus operandi. Churches, Mosques, temples and other paces of religious expression were called into a paradigm shift to position themselves for relevance in a world that was caught in the web of uncertainty amid the introduction of Covid19 precautionary measures. These measures subverted the very conventional and traditional ways in which places of worship operated. In March, Muslims for instance, marked the holy month of Ramadan without the usual fanfare and ritual symbolism associated with the month. The BBC reported an Imam at the al-Ikhlar centre in Adams town, Cardiff saying. "There will not be an evening meals together and there will not be congregational prayers" https://www.bbc.com/news/uk-wales52385101, Accessed June 18, 2020). The Catholic Church, known for a dramatic and symbolic celebration of Lent, also had to pass through the day without much activity for it. Easter celebrations were no celebrations. This generated debates both within the churches and in the social media (https://www. voanews.com/science-health/coronavirus-outbreak/, Accessed June 18,2020$)$. Some of the churches were now beginning to conform to the directives.

Earlier on, on March 21st, 2020, although the country held an inter-faith intercessory prayer at State House, Nairobi, dubbed "Prayers of forgiveness" that sought for God to spare the nation from doom if the people turned from their evil ways (https:// youtu.be/yza7hYDZh7E, Accessed May 21, 2020), this seems to have been the last national prayer day and religious congregation. The only other ceremonies witnessed at the time of restrictions over religious gatherings were ritual ceremonies held by elders to curse and exorcise the virus from the country. For example, in one of the counties, Kipsigis elders conducted a ritual by the river to expel coronavirus from Kenya. They sacrificed a ram and poured the blood into a river and the downstream flow of the river with the blood was a symbol of the corona being drifted down. Similar rituals were witnessed in Kikuyu and Kuria land. These rituals were done within the framework of the ministry of health protocols and as such, the participants wore masks and kept social distance. Regardless, there were no publicly proclaimed healing miracles from coronavirus reported.

It was not until after the curve flattened around October, that the President called for a national holiday dubbed Huduma Day on October 10, 2020, and declared a weekend of prayer, with inter-faith prayers held at State House in Nairobi. Before then, the government had in the month of August loosened the directives to allow no more than 100 congregants to meet, following recommendations made by and Inter-Faith Council that was formed on June 17, 2020 to advice on matters faith in the face of covid-19. The council was mandated to guide on the development of stringent protocols for a phased re-opening of places of worship in guidelines expected to allow a more participatory mode of worship under the covid-19 pandemic.

By and large, our essay is a critical consideration of the narratives that emerged in the context of the ban on religious gatherings that dramatizes the struggle for survival for a sector of the society that, in the main, enjoyed considerable autonomy and freedom of worship before the advent of the virus. The essay presents the repositioning of the Church towards the use of digital media and subsequently, how spirituality was framed in Kenya, in the context of a global pandemic. The essay further shows how the social media found renewed relevance as it provided churches a platform for alternative existence in the face of the ban. It became the pulpit through which the church continued to actualize its mandate. 


\section{RELIGION AND SOCIAL MEDIA IN THE ERA OF COVID-19}

The pandemic almost paralyzed the core mandate of churches. The ban on the physical church had posed serious challenges on evangelism, church finances in the form of tithes and offerings; relevance of church leaders; inter-personal relations and social activities among other aspects. This section will explore some of these.

\section{Evangelism}

As already noted, mainstream and social media has in the past been used for evangelism. In Kenya, some well established churches like Christ is the Answer Ministries (CITAM), Repentance and Holiness Ministry, and the Anglican Church among others, have evangelism programs on radio, television as well as online. Repentance and Holiness Ministry, for instance runs "Jesus is Lord" Radio station, which can be accessed through www.jesusislordradio.info. Other evangelical ministries in Kenya such as Maximum Miracles and Jesus is Alive Ministries (JIAM) are no strangers to Television and radio preaching as they have had a long tradition of preaching through these forums. CITAM is perhaps one of the most social media savvy ministries. The ministry has a fully-fledged Broadcasting service and their Hope television broadcast is replete with a professional sign language interpreter. The ministry also has CITAM Youth and Teen nation (CITAM YTNation) that brings youth together "to know God and make Him known", according to their online mantra, https:// www.facebook.com/CITAMYTNation/. It also has the CITAM Church Online (CCO), with the harshtag \#Church Everyday, https://www.youtube.com/channel/

UCiTB3GGVVdj6Q0omF7Z66Qw. In the era of Covid-19, one of the posting on CCO read: "The church may be empty but we are the body of Christ and god still dwells among us. Catch Rev. Grace Bukachi as she encourages us through the topic "My Testimony"

With the corona pandemic, these mainstream channels and social media outlets became appropriate for evangelism. Although social media seems to have largely been embraced by the Pentecostal churches, in the wake of Covid-19, the mainstream missionary churches, mainly considered rigid and traditional in the sense of their worship, had no choice but to join in. A missionary Catholic Priest from the United States working in Kenya noted that the Covid-19 crisis as offering an opportunity for the Church to get on to new platforms. He argued that if the church encounters a problem, it should turn the problem into an opportunity. In one of the social media platforms, he said:

Many Catholics in Kenya have turned the problem of closed churches on Sunday into an opportunity. The new way of becoming Catholic church is digital or virtual. We have a new kairos. We have a new online practice. Let us seize this moment, Carpe diem, to proclaim the good news of Jesus Christ to all people.

For this Priest, Covid-19 has brought something new that the church needs to tap into for its missionary work. He describes what they call Online small Christian Communities (OSCC) or Virtual Small Christian Communities (VSCC) or Digital Small Christian Communities (DSCC) as the new Church in the face of the lockdown on churches. Similar accounts were also witnessed with the Anglican Church, with church leaders conducting services on Sundays $8 \mathrm{am}$ and Wednesdays 6PM that also streamed on official Archbishop and ACK Facebook pages. Facebook, WhatsApp, and YouTube became the medium through which the Church can claim back its place in evangelism. Members were asked to tune in to Facebook, form watch parties and share with contacts as a way of enlarging the frontiers of the church. This showed the quick and significant shift from the physical to the virtual Church. Church leaders would ask their members to share sermons, start watch parties and share posts that not only spread their messages but also helped advertise them their ministries as a way of expanding their reach. In the online sermons' it is common to hear, "...let us know from where you are watching us from..."-a strategy for determining the spread of its viewership. The online sermons have the diffusive capacities to reach populations in vast geographical locations and disparate time zones. In most of these sermons the preachers are alive to the absence of a real live congregation. Aware of being followed beyond the physical church they address their absent congregations and encourage them to invite friends, form watch parties, give feedbacks and comments and support the Ministry. They put their Paybill M-Pesa and bank account numbers are played on the screen for the members to give their tithes and offerings.

This was an unfamiliar terrain to many of the churches but the only way to keep in touch with the faithful, was through the mainstream and social media. Although the reach in some areas like the rural areas might have been challenging given the network coverage limitations, social media played a critical role in times of uncertainties. Part of the myths and misconceptions that religion and religious leaders might not have been able to unravel is the image that has always been created of an institution that provides hope and healing at the time of need. Although as already seen there were efforts to invoke the spiritual world to provide solutions, the conditions seem to have been similar in many parts of the globe. Countries like Italy and Rome that were largely affected held prayers as a sign of surrender after all else had failed. With the world watching, people might have resulted into caution as reality dawned around the misconceptions that might have been propagated about the cause of the virus, including sinful nations that needed redemption and healing. Although the religiosity of Africans as Mbiti (1969) argues is notorious, the virus gave people no window for "watch and see." The seriousness with which most congregants took the government's directives were an indication that Covid-19 has caused fear and panic among the people.

\section{Inter-Personal Relations}

With the shift from the physical to the online church, and the struggle for survival in the midst of the pandemic, families and individuals were left on their own. Although a little help would be received from the government and a few humanitarian organizations, these were targeted to the desolate. The fear that the virus instilled among people meant that even close friends 
would be cautious to meet and interact in fear of contracting and spreading the same to their families. As the virus continued to kill millions of people all over the world, the truth now dawned on congregations that some government bans were warranted. Although the number of deaths in Kenya and other African nations were not as high, people still remained cautious, with the Ministry of Health $(\mathrm{MoH})$ in the country promising that the worst was yet to happen. In spite of the cautions, in most pockets of the country that had not been marked as hotspots for the virus, people continued to interact, mostly without the necessary precautions. Pubs would have front doors closed but people would find their way in through back doors. The virus, with time, was branded a virus of city men and women, and these would be asked not to travel upcountry in fear of spreading the virus to the rural areas. In fact, the rural folk would rather send food harvest through courier services for their kin in the cities than have them visit in the villages. These were odd times. In the meantime, the statistics continued to soar.

For the religious groups, without physical congregations, the faithful found alternative ways of socializing. Individual families would be shown on TV holding meetings in their homes, and sharing in the word of God. Parents held Sabbath and Sunday Schools for their children, with the TVs and radios becoming virtual means to educate them. Parents sought for TV and social media platforms that could offer this much needed service for them and their children. The availability of these media seems to have rendered church leaders irrelevant in the time of the pandemic. It was now time for the pastors to find a way of reaching out to their members not only with the message of hope but also to plug in the gap that was created by failure to attend physical church. A Catholic Church priest noted that they encouraged members to meet virtually through their small Christian Communities, for home fellowships through platforms such as zoom and Google Meet. But how many could afford? How many knew how to use these virtual facilities? A physical distance between pastors and their members was evident. A pastor of a church in Eldoret took on social media to lament that his church members were not picking calls, and he was unable to get the much-needed help in the time of need. Another Pastor in Nairobi who also decried the changed situation of men of the cloth echoed the sentiments of the Eldoret pastor. He lamented that he was now preaching to an empty auditorium as he asked people to be care for preachers. The challenges faced by masses in the era of the virus, left many individuals and families struggling. As the economic effects of the continued to bite, everyone was fighting for his/her own. Although the social media allowed for congregations to meet virtually through Google Meet, Zoom, Webinar, among many, not all had access, and it was never the same like had been for physical services.

On social services provided by the Church, some of the churches continued to conduct weddings but only with the bridal parties and parents. The rest participated through zoom. Some leaders agreed to conduct burials on site, but could not officiate funeral services, given the government's directives. Some community activities such as burials became nightmare experiences, with corpses disposed off unceremoniously and family members barred from interacting with the corpse, or holding any gathering beyond 15 persons.

Although the social media platform has also opened a dialogic space in which people have continued to debate and dialogue about spirituality, there are limitations that come with the same. This is a complete departure from the conventional pulpit structure. Social media has that has not engendered debates around a structured system where unanimity on matters spiritual issues can be reached. People identify physically with churches whose doctrines they subscribe to, and subsequently, a virtual way of connecting to the Church became alien to many. Virtual space is challenging in controlling social activities and social institutions, including the Church, whose traditionally, vests moral authority on leadership. With the ability of congregants to disguise in social media platforms like Facebook and Twitter, this authority is challenged.

When in the month of August, the government allowed for 100 church members per service of 1 hour, there was still uncertainty on whether people should attend or not given the fear of the virus. Although this came with strict directives, the churches still remained empty. Many questioned the formula of 100 congregants per hour. Others argued that since they had survived for months without church worship, they could still wait. Although this was a relief on the part of the pastors, with signs of getting their churches back, the damage had already been done. The acceptance of listening to the voice of God and the wisdom of science can be interpreted to imply a Church that is now more than ever willing to accept the efficacy of science over faith. The phased or partial openings in which only 100 members would be allowed into one service is an indication that the myths and misconceptions that infections do not happen in houses of God, and that congregants are protected, cannot find a place in the 21st debates around infectious diseases. Further, some of the restrictions on the age brackets allowed for Church service, limiting it to between 13 and 58 years, and later to between 2-60 years, implies that reality, rather than myths of healing and miracles in the churches, made sense, even to "men and women of cloth."

Churches that were unable to pay rent were permanently closed, and others had lost congregants who did not find the relevant to churches in times of need. In the month of September, and just at a time when a scandal of embezzlement of Covid-19 funds emerged, with accusations of collusion between the $\mathrm{MoH}$ and Kenya Medical Supplies Authority (KEMSA) in the 19multibillion scandal, the government relaxed the Covid-19 social limitations. Churches, pubs and restaurants were opened. Schools also began to open up in the month of October. A disease that began with a lot of fanfare and restrictions seemed to end abruptly albeit with some caution from the $\mathrm{MoH}$ for people to keep guard on the pre-cautionary measures. This has been met with resistance and a narrative that the disease was about government securing Covid-19 funds is used by the masses to reject some of the MoH's directives. In most parts of the country, life seems to have slowly crept back to normal, even with warnings over rising cases, and a second wave. 


\section{Relevance of Church Leaders}

The place of religion in Kenya is eminent. In times of crisis, political leaders, who are mainly seen to visit churches to use the pulpit for political gains, call on prayer days throughout the nation. The predicament presented by Covid-19 was however different. The disease discouraged such meetings, and as part of the precautions, all religious congregations were banned. The initial reaction of the government, and Kenyans in general, was to hold national prayers to ask God for forgiveness for known and unknown sins. An interfaith prayer was held 9 days after the first case had been discovered in the country, under strict Covid-19 guidelines that the Ministry of Health had already set in place. This was however a one-day affair. The fear and uncertainty that was to later engulf the country as the virus spread, mainly in cities, left many confused on whether religion was relevant in times of such crises. Cartoonists were quick to capture the confusion of the moment depicting the virus taking over the pulpit as the pastors scampered for refuge. The indication was that the virus was enormous and unmatched by the faith. Faith and hope as the glue that holds congregants together was on the line.

Disasters in the past have attracted myths around certain leaders, including traditional. A case reported from Tanzania in 2012 of a 74-year-old man, a HIV miracle healer, cost many their lives and health. "Babu" the traditional healer had proclaimed that God had visited him in his dreams and revealed HIV cure. He is said to have "treated" four million people living with HIV by giving then one cup of a concoction of herbs that he had intently and under spiritual guidance, brewed. Similar accounts, albeit dramatic were heard in Kenya. A child born in Mombasa in the middle of the pandemic is said to have made utterances immediately after birth saying that black tea is a cure to Covid-19.

In a broadcast posted on YouTube on March 6, 2020, the Leader of a Pentecostal Church, a renowned controversial Prophet, expounded on past prophecies of 2003 and 2004, and drew connections between these prophecies and Covid-19. To him, his prophesies had been fulfilled. He observes that the reason for retrieving the Prophesies is so as to explain why the earth is the way it is today. He says that he had prophesied a big disease coming from Asia that would be a huge distress and would create a disease emergency upon the face of the earth. He explains that: "The Lord already took me to hospitals 4 years ago where I talked with doctors who told me that they needed to get a culture in Wuhan and grow the virus in petridishes and test and find out what kind of virus it is. . But there was no cure." In a similar instance, and through social media the Apostle of one of the mega Pentecostal Churches in Kenya, on his homepage on Facebook also claims to have been used by the Lord to warn people about the current global situation. He has a preaching in which he claims to be prophesying about Covid-19. In the short clip, which he claims to have retrieved from his sermon archives and which he posted on June 30, 2020 with a post: This is what the Lord send me to prophesy last year before the pandemic came. I did, but a prophet is no prophet in among his own. I pray that God will have mercy on us. In the clip, he is heard saying: Something wrong is about to happen, something wrong is about to happen. Not to
Kenya, but all over. People are worshipping the devil. If you pray to God, now it is time.

Although it is not possible to discern the contexts within which these past clips were made, and ascertain their authenticity, the leaders seem to try and find relevance at a time of crises. The fact that they have following in the radio stations and social media platforms gives them an upper hand over churches that are yet to establish the same. Some pastors of well-established churches were quick to hold online panels to discuss issues targeted on Covid-19 situation in the country. One of the Deliverance churches in Nairobi held bi-weekly panels on various topics including wealth creation; and, raising children, in the era of the pandemic. They invited congregants to join them through social media. One of the annual face-to-face church events branded "annual spiritual week" was held online and streamed through Facebook and Twitter. The leader of the church was quick to indicate on his Facebook page that "there is no social distancing in the Spirit." Providing hash tags: \#DOR 2020, \#WeAreTheChurch, \#IamDCIU, for the members to follow and contribute to the debate. Pentecostalism has been hailed as a mega movement across the continent, and in the era of technological advancement and invention, there seems to be nothing that can stop the spread of the Gospel by these churches. Limited accounts of online interactions were noted among the more preserved and traditional Christian denominations, especially the African Independent Churches (AICs). Although a few appeared on TV interviews to explain how their members were coping with the situation, very little exists on social media that speak to their engagement via these media.

Although from these accounts the image that is presented of these churches is that of active communities, it should be noted that given the population of Christians in Kenya and number of many Christian denominations, this is just a minute fraction of activity on the part of the Church. The majority did not find ways to reach out to the members. In fact, quite a number of churches closed down for lack or finances to sustain the rent. Many ministers of the word remained maim, having been swept by an unfamiliar current. The voices of these leaders were heard in unison after the directives for closure had been relaxed. They questioned the 100 per hour directive stating that this was an insult to churches and other places of worship given that similar directives were not given for other social places including pubs and supermarkets. Their voices were also heard in the month of September, when a number of them united to condemn the Covid-19 corruption scandal associated with KEMSA and $\mathrm{MoH}$.

\section{Tithes and Offerings}

The Church leaders, and especially the fulltime ministers of the gospel, and who solely depended on the offerings and tithes from the members for sustenance had to come to terms with a congregation that had not envisioned a form of giving that was completely dislodged from going to church. To many churchgoers, offerings and tithes are "taken" to church when one goes for service. Although the televangelists had been asking their followers to send tithes and offerings through 
electronic money transfers, many church going Christians still believe in the conventional tradition of going to church with their tithes and offerings. Majority of Church leaders have institutionalized and mainstreamed a form of giving that works effectively only through a physical presence in the church. The practice of tapping blessings by walking to the pulpit and handing over money to the preacher when one feels "touched," blessed or inspired by a section of the sermon is very common among Pentecostal churches. Preachers of what has come to be called gospel of prosperity have manipulated to the point of intimidating their members. Everybody in the congregation feels accepted and personally recognized if they are fiscally connected to the Preacher. Literature on gospel of prosperity show how church leaders have amassed great fortunes simply from what their faithful members give as a way of blessing the servant of God and tapping into the blessings (Osgood, 2008; Mayrargue, 2008; Parsitau and Mwaura, 2010; among many). The physical presence of the faithful Pentecostal churches allows for the church leaders to harvest a number of offerings in the name of "seed planting," "blessing the servant of God," "miracle-invoking-giving," "development projects," and "Pastors' welfare project," among others. It is no wonder that in a number of countries, including in the West, there have been calls to monitor the activities if the Churches, including imposition of taxes on the monies generated. Of course, this has attracted backlash from the church leaders and their faithful followers, citing constitutional freedoms to faith and belief. With the ability control their church resources; not pay taxes; and, no accountability mechanisms, this lot has flashy lifestyles. They live in palaces and drive big engine vehicles. They have bodyguards, and are affiliated to political leaders, who use them to gunner added votes from the faithful followers of the Ministers of the word. To them, and their followers, all these are manifestations of the blessings of the Lord. They are the favoured and blessed of the Lord.

In the Covid-19 era, with the ban on the physical church, though it did not impose a ban on these forms of giving, this brought a significant check on the practice of tithes and offerings, impacting heavily on the pastors' take home. The situation was made worse by the economic downturn, with many losing their jobs. The church members were themselves struggling to make ends meet. On the Facebook post of one of the Church leaders, a Bishop, of a prominent ministry, made a post that said: "Ye are a chosen generation, a royal priesthood, and a holy nation, a peculiar people. REJECTION IS NOT YOUR PORTION. You are accepted beloved." Bishop's post, which was accompanied by the portrait of him and his wife, received a number of "Amens," but in the midst of these an individual posted: "My fellow Christians, please help me am in need please. Even KES. 50 from each and every one of you, I will appreciate so much." The church leader was quick to interject and ask the fellow not to raise funds in that platform, terming it as unfair and an influence for the platform to lose its credibility. This may be an illustration of the economic struggles of the church members. It also raises questions as to what the role of the social media is in framing online spirituality. One would have expected the church leader to pay attention to the plight of this individual and perhaps engage him/her on a more friendly and accommodating manner than a fast dismissal. Although a probable reason might be the indeterminate nature of social media personas, a fair hearing and a more mature handling of the issue might have helped.

WhatsApp forums and Facebook are awash with calls for church members to continue worshipping the Lord and giving their tithes and offerings from their online pews. It is still not possible to determine the success or otherwise of this venture but all indications are that not very many Christians responded to the call to send their offerings and tithes through Mpesa and other non-physical ways. A narrative that came out in the social media, complete with a photographic caption perhaps captured the plight of many. A pastor who relied on the church offerings for sustenance, with the challenges posed by the pandemic, sold church belongings-chairs, tables, Bibles and padlock. The pastor lamented: "We are all struggling to survive and what I did, I did to feed my family and save them from hunger since no church member was returning my calls. Today the seats are empty and we will have no offerings and tithes. How are we going to survive?" Prior to the incident, he had hired a few members to Videotape his March 22nd sermon and posted it on Facebook. In the sermon, he had called on his members to honor God with their finances and argued that coronavirus should not be the reason for people. He said, portrayed God as a healer on condition that the faithful gave offerings. Such myths and misconceptions as used by pastors to hoodwink the faithful seem to have appeared at the wrong time. Everyone was struggling to keep afloat.

So, whether to tithe while not attending church or to wait until the physical attendance resumes has become now a matter of doctrinal interpretation. But there might not be a general agreement about digital tithing and offering among all church leaders. One Pastor for instance, observed that the corona pandemic has provided an opportunity for leaders, who have been self-seeking and materialistic church leaders, exploiting their members and manipulating them to give money, to now come to the aid of their members and help them in times of need.

\section{CONCLUSION}

The misconceptions that pulpit religiosity is here to stay was challenged by the events of Covid-19, just in the same way other forms of face-to-face interactions were; including education and careers/work. It seems, challenges such as pandemics, posed by the global village that the world has become, will require readjustment from the norm. Technological advancement and discoveries is taking us to new heights and depths. Covid-19 forced humanity to rethink the norm in schooling, spirituality and careers. The pandemic has amplified the changed circumstances of the church of the 21st century and recreated a neo-modern spirituality that is mediated in the social media. Google Meet, Zoom, Webinars, Facebook, Twitter, Instagram, among many, are discoveries that kept the spirituality alive. The proliferation of the Online Church services among mainstream and Pentecostal churches is a remarkable way through which the 
church has exerted its relevance to a world that is slowly being taken over by technology. It would be interesting to see how this new spirituality and the resultant small online church communities and the digital church would stand out in the post Covid-19 Christianity.

\section{DATA AVAILABILITY STATEMENT}

The original contributions presented in the study are included in the article/supplementary material, further inquiries can be directed to the corresponding author.

\section{REFERENCES}

Amanze, P. O., and Wogu, C. N. (2015). Internet Evangelism: An Effective Method for Soul-Winning in the Seventh-Day Adventist Church in Nigeria. Aamm 11, 149-170. doi:10.21806/aamm.2015.11.08

Asamoah-Gyadu, J. K. (2005). Anointing through the Screen: Neo-Pentecostalism and Televised Christianity in Ghana. Stud. World Christianity 11 (1), 9-28. doi:10.3366/swc.2005.11.1.9

Asamoah-Gyadu, K. (2015). “"We Are on the Internet”: Contemporary Pentecostalism in Africa and the New Culture of Online Religion," in New media and Religious Transformations. Editors R. Hackett and B. Soares (Bloomington, Indianapolis: Indiana University Press), 157-170.

Carl, F. (2015). "Music, Ritual and media in Charismatic Religious Experience in Ghana," in Singing a New Song: Christian Congregational Music Making and Community in a Mediated Age. Editors T. Wagner and A. Nekola (Farnham, London: Ashgate), 45-60.

Coleman, S. (1998). Charismatic Christianity and the Dilemmas of Globalization. Religion 28 (3), 245-256. doi:10.1006/reli.1998.0132

Cox, H. (1995). Fire from Heaven: The Rise of Pentecostal Christianity and the Reshaping of the Religion in the Twenty-First century. Reading, MA: Addison-Wesley.

Delloitte (2019). Global mobile Consumer Survey. The Kenya Cut. London: The creative studio at Deloitte.

Hackett, R. I. J. (1998). Charismatic/Pentecostal Appropriation of Media Technologies in Nigeria and Ghana. J. Religion Afr. 28 (3), 258-277. doi:10.1163/157006698x00026

Mayrargue, C. (2008). The Paradoxes of Pentecostalism in Africa. Sub-saharan Africa Program. Available from: https://www.ifri.org/sites/default/files/atoms/ files/mayrargue_the_paradoxes_of_pentecostalism.pdf (Accessed September 10th, 2020).

Meyer, B. (2003). Impossible Representations. Pentecostalism, Vision and Video Technology in Ghana. Mainz, Germany: Johannes GutenbergUniversität, Department of Anthropology and African Studies. Working papers No. 25.

\section{ETHICS STATEMENT}

Ethical review and approval was not required for the study on human participants in accordance with the local legislation and institutional requirements. Written informed consent for participation was not required for this study in accordance with the national legislation and the institutional requirements.

\section{AUTHOR CONTRIBUTIONS}

All authors listed have made a substantial, direct, and intellectual contribution to the work and approved it for publication.

Nyamjoh, F. (2015). "Foreword," in New media and Religious Transformations in Africa. Editors R. Hackett and B. Soares (Bloomington, Indianapolis: Indiana University Press).

Osgood, H. (2008). Pentecostalism: Global Trends and Local Adjusttnents. J. Eur. Pentecostal Theological Assoc. 28 (1), 62-76. doi:10.1179/jep.2008.28.1.006

Ozili, P. K., and Arun, T. (2020). COVID-19 Pandemic and Economic Crisis: the Nigerian Experience and Structural Causes. Journal of Economic and Administrative Sciences 37 (4), 401-418. doi:10.1108/JEAS-05-2020-0074

Parsitau, D., and Mwaura, P. (2010). God in the City: Pentecostalism as an Urban Phenomenon in Kenya. Studia Historiae Ecclesiasticue 36 (2), 95-112.

Togarasei, L. (2012). Mediating the Gospel: Pentecostal Christianity and Media Technology in Botswana and Zimbabwe. J. Contemp. Religion 27 (2), 257-274. doi:10.1080/13537903.2012.675740

Togarasei, L. (2015). Modern/charismatic Pentecostalism as a Form of 'Religious' Secularisation in Africa. She 41 (1), 56-66. doi:10.25159/2412-4265/95

Ukah, A. (2006). Branding God: Advertising and the Pentecostal Industry in Nigeria. Liwuram: J. Humanities 13, 83-106. doi:10.1163/15700660360703141

Conflict of Interest: The authors declare that the research was conducted in the absence of any commercial or financial relationships that could be construed as a potential conflict of interest.

Publisher's Note: All claims expressed in this article are solely those of the authors and do not necessarily represent those of their affiliated organizations, or those of the publisher, the editors and the reviewers. Any product that may be evaluated in this article, or claim that may be made by its manufacturer, is not guaranteed or endorsed by the publisher.

Copyright (C) 2021 Kilonzo and Omwalo. This is an open-access article distributed under the terms of the Creative Commons Attribution License (CC BY). The use, distribution or reproduction in other forums is permitted, provided the original author(s) and the copyright owner(s) are credited and that the original publication in this journal is cited, in accordance with accepted academic practice. No use, distribution or reproduction is permitted which does not comply with these terms. 